\title{
DESIGNING AND DELIVERING A MEDICAL INFORMATICS COURSE TO GRADUATE HEALTH MANAGEMENT STUDENTS
}

\author{
Sathasivam Mathiyalakan, Winston Salem State University, mathiyalakansa@wssu.edu
}

\begin{abstract}
Medical Informatics is a rapidly growing field that lies at the intersection of patient care, the healthcare system environment, and information and communication technologies. In this paper, we report on the development of a required graduate course in Medical Informatics. The overall objective of the course is to provide the students with knowledge of: a) the organization of health information to support action, c) how IT creates value, and 3) managing change within the IT project management environment. The students will use project management and decision analysis software to gain a better understanding of tools and techniques needed to function productively within a healthcare environment.
\end{abstract}

Keywords: Education, E- Health, Health care, Informatics, Teaching

\section{INTRODUCTION}

The American Medical Association defines Medical Informatics as

".. has to do with all aspects of understanding and promoting the effective organization, analysis, management, and use of information in health care. While the field of biomedical and health informatics shares the general scope of these interests with some other health care specialties and disciplines, biomedical and health informatics has developed its own areas of emphasis and approaches that have set it apart from other disciplines and specialties. For one, a common thread through biomedical and health informatics has been the emphasis on technology as an integral tool to help organize, analyze, manage, and use information."

While distinctions exist, we hold the view that the terms Medical Informatics, Health Informatics, healthcare Informatics, e-Health are related terms.
Additional definitions of the term Medical Informatics is at the American Medical Information site at http://www2.amia.org/nside/faq/whatis.asp.

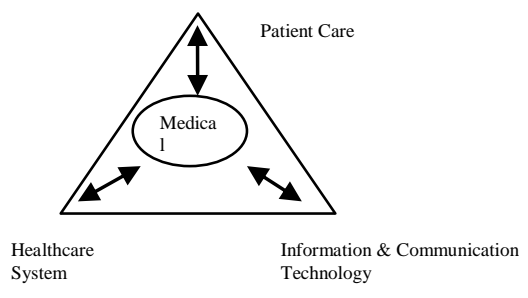

Figure 1: Domain of Medical Informatics

The three domains Patient (Clinical) Care, The Healthcare System, and Information and Communication Technology (ICT) form the foundation on which the field of Medical Informatics rests (see Figure 1). ICT is a broad field that encompasses all aspects of computer and related fields including Software, Hardware, People, Services, and Human Computer Interaction. Gardner et al. [1] provide details on core content of this field.

The Winston Salem State University is located in Winston Salem, NC. It is one of the 16 higher education institutions that comprise the University of North Carolina System. Winston Salem is served by two major hospitals, Wake Forest University's Baptist Medical Center and Forsyth Medical Center (a unit of Novant Health) as well as Sara Lee Center for Women's Health.

The Master of Healthcare Administration (MHA) program began in fall 2008 with 10 students. The MHA degree is a 15 courses program with courses in Organizational Behavior, Economics, Accounting, Financial Management, Decision Analysis, and Marketing. Medical Informatics is one of the required courses within this program. This course 
was designed by IT faculty with the emphasis on the analysis and use of technology within the health care industry. This paper describes the efforts in the development of a graduate course in Medical Informatics. This course will be offered as a required core course to MHA students for the first time in summer 2009.

\section{BACKGROUND: RATIONALE FOR THE COURSE}

Healthcare expenditure constitutes a major spending of the US government's annual budget. According to National Coalition on Health Care, the health care expenditure is expected to rise by $6.9 \%$ in 2008 and that the total expenditure is around $\$ 2.4$ Trillion or $\$ 7900$ per person and represents $17 \%$ of the gross domestic product. The Coalition also suggest that in 2008 employer health premiums rose by $5 \%$ and that employer premiums totaled $\$ 12,700$ for a family of four.

Two significant national efforts were proposed this decade to control health care costs and to reduce inefficiencies, duplication and waste, inflated prices, excessive administration expenses, and poor management. These two efforts have the use of Information Technology (IT) at its core to reduce cost and improve health care. In 2004 President Bush established the goal of the availability of electronic medical records to most patients within the next ten years [7]. Other initiatives proposed by President Bush include: instant availability of updated patients' medical records irrespective of the location, avoiding un-necessary tests and hospitalization through the better use of information, reducing medical errors, public health information reporting procedures, gathering of non identifiable information for research and better treatment outcomes, protecting privacy, investing in local health exchanges, creating common medical languages and federal health information standards, and E-prescribing.

On February 17, 2009 President Obama signed the American Recovery and Re-investment Act into law. A component of this law is the provision of $\$ 20$ billion for healthcare IT infrastructure investment, adoption of healthcare IT by providers and other entities, grants for integrating IT into clinical education, research and development programs, and funding to establish or expand medical informatics programs in higher educations.
These events and statistics suggest that the field of Medical Informatics is a growing field and is likely to play an important role in US economy. As healthcare is one of the key growth fields with multitude of career opportunities of graduates, there exist several possibilities for research and curriculum development. A review of literature indicates the existence of few articles describing efforts directed at curriculum development within this field ([3], [8]).

\section{COURSE DESIGN}

\section{$\underline{\text { Course Description and outcomes }}$}

To ensure that the MHA degree meets the needs of the students and provides a program of study that leads to a degree of substance and quality, WSSU is currently seeking the accreditation of the Commission on Accreditation of Healthcare Management Education (CAHME). CAHME ensures that its members provide quality education and are engaged in continuous improvement through peer review. MHA 6304 is designed to meet CAHME's graduate program accreditation standards. The criteria for accreditation is outlined at http://www.cahme.org/Accreditation/Official CAHMECriteriaFall2008andBeyond.pdf

This course was designed to meet the following goals set by CAHME for accreditation:

III.B.7 Information systems management and assessment

III.B.11Written, verbal and interpersonal communication skills

III.B.16 Ethics in business and clinical decisionmaking

MHA 6304 is also designed to meet the following two applied and integrative learning competencies:

III.C.1 The Program will ensure that students demonstrate critical thinking and problem solving skills as well as management competencies in applied, experiential settings.

III.C.3 The program will provide, throughout the curriculum, opportunities for students to participate in team-based activities. 
Based on these requirements and the course description noted at other comparable institutions, the learning outcomes were developed as:

1. acquire familiarity with core concepts in medical informatics including decision support systems in clinical environments and other health care settings

2. identify behavior change among providers and patients to achieve better health outcomes

3. approach health data from a systems analysis perspective

4. learn to manage healthcare data in the context of emerging regulations

5. develop a clear understanding of information security measures

6. develop an understanding of hardware, software, networking, and communications within a health care context.

The course description and learning outcomes were developed as part of the process by which the School of Business \& Economics at WSSU sought the approval of the School of Graduate Studies for MHA 6304. The Instructor places a great emphasis and value on developing a course that has both theory and practice. As the course will be offered for the first time in summer 2009, the Instructor has the necessary latitude for course re-design and structuring of the course based on teaching experience, student feedback, and structure of similar courses at other institutions.

\section{COURSE OUTLINE \& DELIVERY}

Based on a review of CAHME accredited Medical Informatics courses, we developed the following description for MHA 6304:

This course is designed around three themes of healthcare informatics: 1) the organization of health information to support action, 2) how IT creates value, and 3) managing change within the IT healthcare environment. By focusing on operational flows rather than computers, we recognize that business and clinical needs must drive technology choices. Students will become conversant in the key operations that are driving health informatics development, while identifying the reasons for the all-too-frequent failures of health care computer system implementations. Lessons from other industries which are often ahead of healthcare will be (cautiously) applied.

The course will focus attention on both the integrated delivery system (hospital-driven organizations) and the private medical practice environments of informatics. The course project will be to evaluate a patient-care system at the student's home organization/institution using the dimensions discussed throughout the course.

To meet the requirements set forth in the course description, the author selected as the major text "Making Information Technology Work" by Kropf and Scalzi [5]. The major reason for this this text over others in the marketplace such as ([2], [9]) is its emphasis on healthcare IT value assessment and project implementation. The class will use "Project Management for Healthcare Informatics" as a supplementary text [4].

\begin{tabular}{|c|l|l|}
\hline Week & \multicolumn{1}{|c|}{ Topic } & \multicolumn{1}{c|}{ Labs } \\
\hline 1 & Introduction & \\
\hline 2 & $\begin{array}{l}\text { Estmating Benefits } \\
\text { Financial Analysis using } \\
\text { Excel } \\
\text { Case 1 Discussion }\end{array}$ & $\begin{array}{l}\text { Financial } \\
\text { Evaluation of } \\
\text { Projects }\end{array}$ \\
\hline 3 & $\begin{array}{l}\text { Creating a Business } \\
\text { Case for a Major } \\
\text { Information Technology } \\
\text { Investment } \\
\text { Case 2 Presentations } \\
\text { Flowcharting using MS } \\
\text { Visio }\end{array}$ & $\begin{array}{l}\text { Financial } \\
\text { Evaluation of } \\
\text { Projects }\end{array}$ \\
\hline 4 & $\begin{array}{l}\text { What Is Project } \\
\text { Management? } \\
\text { Project Management } \\
\text { using MS Project }\end{array}$ & Project \\
\hline 5 & $\begin{array}{l}\text { Post-Implementation } \\
\text { Audits } \\
\text { Benefits Realization }\end{array}$ & Project \\
& Management \\
\hline 6 & $\begin{array}{l}\text { Service Level } \\
\text { Agreement (SLA) } \\
\text { Negotiation Exercise } \\
\text { Case 3/4 Presentations } \\
\text { Course Wrap Up }\end{array}$ & \\
\hline
\end{tabular}

Table 1: Course outline

Using the learning competencies, the course was structured to provide a student with a knowledge of a) making a business case for information technology, project management during 
implementation, perfromance management after implementation, and the necessary tools. Table 1 shows the course outline for the 6 week duration.

The proposed teaching methods are:

Class Discussion: Class discussion will form an important source for knowledge sharing among the course participants. Rather than using the traditional mode of lectures where the communication is often one way, student led class discussion will be used to identify new concepts impart knowledge. The instructor will play the role of a facilitator and guide the discussion.

Case Assessment \& Presentation: The text has four cases on various aspects of healthcare value assessment and project implementation. As some students may not have taken a course with case discussion, the instructor will lead the discuss ion for the first case. Students then form small groups and lead the discussion for the three remaining cases. The use of cases as an important teaching method will meet CAHME learning competencies III.C.1 and III.C.3.

Software Use: The use software plays an important role in this course as it serves to reinforce the concepts learnt. The students will use Microsoft Project $^{\mathrm{TM}}$ to learn project management skills such as planning for resources, scheduling and assessing current status, and managing finances. They will also use Microsoft Excel ${ }^{\mathrm{TM}}$ to learn decision making skills in financial analysis of projects. The students will also use Microsoft Visio $^{\mathrm{TM}}$ to gain skills in diagramming and flowcharting. Both in class lab assignments and homework assignments will be used to reinforce the skills.

Quality Improvement Project: In the Quality Improvement Project, the student presents an information systems or technology plan for improving the quality of a health care service. The student will select a service (e.g., ambulatory pediatric services in a small group practice or hospital radiology services) and define an information system (or enhancement to an existing system) that would improve customer satisfaction, clinical quality, or both.

Service Level Agreement (SLA) Negotiation Exercise: The purpose of this exercise is to help students better understand SLAs and introduce them to the process of negotiating with a vendor. Student teams develop a negotiating position. They report out with either customer teams going first, or vendor teams.

\section{SUMMARY REMARKS}

In this article, we present the efforts directed at the development of a Medical Informatics course for students enrolled in the MHA program at Winton Salem State University. Emphasis is placed on developing a course that has both theory and practice. The course will be offered for the first time during the summer 2009 session. Based on the student feedback and Instructor experience, the instructor plans to re-examine the course description, goals and learning outcomes, syllabus, and delivery methods and make the necessary adjustments for the next offering in summer 2010.

\section{REFERENCES}

1. Gardner, R. M., Overhage, J.M., Steen, E.B., Munger, B.., holmes, J.H., Williamson, j.J., and Detmer, D.E. (2009). Core Content for the Subspecialty of Clinical Informatics. Journal of the American Medical Informatics Association, 16(2), 153-157.

2. Glandon, G.L., Smaltz, D.H., and Slovensky, D.S. (2008). Austin and Boxerman's Information Systems for Healthcare Management. $7^{\text {th }}$ Edition. Health Administration Press, Chicago: IL.

3. Hook, S.A. (2003). Teaching health informatics: designing a course for a new graduate informatics program. Journal of Medical Library Association. 91(4), 490 492.

4. Houston, S.M. and Bove L.A. (2007). Project Management for Healthcare Informatics. Springer-Verlag, New York: NY.

5. Kropf, R. and Scalzi. (2007). Making Information Technology Work. Health forum Inc. Chicago: IL.

6. Olmstadt, W. and Hannigan, G.G. (2000). Designing and Delivering a Public Health Informatics Course. Issues in Science and technology Librarianship. Available at 
http://www.library.ucsb.edu/istl/00-

$\underline{\text { fall/article4.html }}$

7. U.S. Department of Health \& Human Services Fact Sheet: Harnessing Information Technology To Improve Health Care. Dated May 6, 2004. Accessed April 8, 2009. Available at http:// www.hhs.gov/ news/ press/ press2004/20040427a.html

8. Wilson, E.V. (2006). The Case for E-health in the Information Systems Curriculum. Issues in Information Systems, 7(1), 299304.

9. Tan, J. (ed.). (2005). E-Health Care Information Systems. Jossey-Bass. San Francisco: CA 